\title{
Deafness and the Educational Rights: A Brief Review through a Brazilian Perspective
}

\author{
Lívia Dias', Ruth Mariani', Cristina M. C. Delou1,2, Erika Winagraski², Helder S. Carvalho², \\ Helena C. Castro ${ }^{1,2 *}$ \\ ${ }^{1}$ Labiemol, Universidade Federal Fluminense, Niterói, Brasil \\ ${ }^{2}$ Pós Graduação em Ensino em Biociências e Saúde, Fundação Instituto Oswaldo Cruz, Rio de Janeiro, Brasil \\ Email: ruthmariani@yahoo.com.br,
}

Received 25 January 2014; revised 25 February 2014; accepted 4 March 2014

Copyright (C) 2014 by authors and Scientific Research Publishing Inc.

This work is licensed under the Creative Commons Attribution International License (CC BY). http://creativecommons.org/licenses/by/4.0/

(c) (i) Open Access

\begin{abstract}
In some countries, the human rights involving a proper education are still a privilege for just a few. In some of these regions, the right for a living with dignity and access to the current knowledge is considered a luxury, especially for people with special needs (e.g. deaf children) as the governmental systems still struggle to provide proper conditions to the regular ones. Herein we showed a brief review on deafness, its history on Brazilian education, the Brazilian sign language and the current need of deaf people for teaching resources at the scholar context to. We have also discussed facts that contributed to the Brazilian deaf education and alternative methodologies for the generation of educational resources that can maximize the teaching-learning process by stimulating the interest of deaf students for the science and biotechnological context. The inclusive educational practice with development of proper educational materials and methods may facilitate the teaching and learning process for everyone, including those with hearing loss. This inclusive practice is of great importance for achieving the educational improvement of all people in any society as a whole. Therefore, this article revisited themes that must be considered in the education of people with special hearing needs to guarantee their right of having a proper education and attention.
\end{abstract}

\section{Keywords}

Deaf, Deafness, Language, Education, Special Needs, Brazil

\section{Introduction}

The history of education in Brazil shows a slow process of inclusion of people with disabilities and/or special

${ }^{*}$ Corresponding author. 
needs at schools, college and universities (Soares, 2005). The law that rules the Brazilian Sign Language (Libras) as a right for the deaf people in this country was established in 2002 and turned the inclusion of this group into the regular school system in a reality that still pursue the quality that these people deserve (Brasil, 2002).

Currently Brazil rules Bilingualism for deaf education through teaching both Sign language and Portuguese. Thus it is important that the student is immersed in this environment as soon as possible using sign language as their first language of choice, working with this language from the earliest stages of educational development together with Portuguese. However the missing signs to gain access to the whole scholar content are clearly detected by the teachers, interpreters and deaf students, which compromise this task (Marino, 2007).

In this article we briefly analyzed the Brazilian data about deafness, the history of deaf education and the need of finding a way of ensuring the right of getting a good education for the people with hearing special needs. In a Brazilian perspective, we reflected about an education that ensures the use of Brazilian Sign Language (Libras) with proper visual tools, and adapted teaching resources in which deaf students can have access to a high quality education.

\section{Methodology}

In order to perform the debate about deafness and educational rights in Brazil, we performed a systematic review and searched the electronic databases PubMed, SciELO EMBASE, the Cochrane Library, and LILACS. Furthermore, we searched the internet and explored references from textbooks and reviews using the following uniterms: deaf, deafness, Libras, right and education.

\section{Results and Discussion}

\subsection{Deafness and Language}

Hearing impairment is characterized by the total or partial loss of the hearing sense. This may be due to the decrease or absence of the proper functioning of parts of the auditory system (outer, middle and inner ear) (Silveira, 2008). Hearing impairment may present different origins: a) hereditary, such as hereditary deafness present in a specific family; b) congenital, as a result of congenital rubella syndrome, meningitis or syphilis; and c) external, by excessive noise or use of medications and drugs during pregnancy, among others. Importantly, the origin of this deficiency is unknown in most cases (Miranda et al., 1998; Redondo \& Carvalho, 2001). In United States, the prevalence of early hearing loss in young adults may be associated with smoking, exposure to noise and cardiovascular risk (Agrawal, Platz, \& Niparko, 2008).

The hearing loss can be classified into mild, moderate, severe or profound (deafness) depending on the degree of residual hearing (Redondo \& Carvalho, 2001). Besides the clinical definition used by doctors and most of the hearing community, deafness has also a socio-anthropological conception defended by members and supporters of the deaf culture.

According to Skliar (1997), Quadros (2003) the clinical concept characterizes the deafness as a disability, inability to listen to the sound, which should be corrected and treated to normalize the deaf people. Differently in the socio-anthropological concept, deafness is a visual experience, a different way of looking at the world from the construction of a historical, political and social reality, with no recognition of the determination of one or another conception as correct. This perception of reality through visual experience constitutes the identity of the deaf culture guided and based on a visual-spatial language (e.g. the use of signs) (Padden \& Humphries, 2005; Castiblanco, 2010).

Some studies about deafness and hearing impairments pointed that the hearing sense is not the unique loss for the affected people. Carneiro (2005) confirmed by neurological examinations that hearing deprivation leads to a reorganization of cortical functions. In fact, the part of the cortex responsible for hearing gains another functions due to brain plasticity (or neuroplasticity) especially at youngest ages (Bear, 2008; Lent, 2010).

The child language acquisition provides his/her contact with a new universe. According to Vygotsky (1993), Lorenzini (2004) the thinking development depend on the language, which is essential for the personal and social development of the individual. The thoughts can be expressed internally and externally, and this occurs through the language that presents an important communicative function (Moreira, 2011). It is also through language that the surrounding world makes sense, gains its own momentum. The language allows men to have their own culture and education, giving also identity, internal and logic coherence. These dimensions give the name of a society in its broadest sense, aggregating all the existential thresholds in a single reality (Silva, 2006). 
Literature emphasized the importance of the language in the construction of the individual identity when people use a language as an instrument that will characterize a community in their own cultural aspects. The language allows the children to understand the world around them as well as human behaviors, and to acquire values, rules and social norms, socializing and learning how to live in community (Capovilla, 2000; Silva, 2006). The communication is representative of the fundamental value of language, allowing people to interact through mutual understanding, exchanges of emotional and intellectual experiences, and planning their lives and their communities.

The absence of language has serious consequences for the social, emotional and intellectual development of the human being. Capovilla (2000) emphasizes that if there is no linguistic basis sufficiently shared and a good level of proficiency to enable a wide and effective communication, the child's world will be confined to stereotypical behaviors learned in limited situations.

\subsection{History of Deaf Education in Brazil}

At the very beginning of the history of Brazilian special education, the school always represented an area of exclusion reserved only to the rich ones. Along with the democratization process, the school education became mandatory for all society, including people with special educational needs and those with disabilities. From that moment on, the process called "inclusion" initiated in Brazil (Brasil, 2008).

Special education in Brazil was accomplished through the specialized care of people with disabilities. Therefore it was proposed an approach different from the regular education, where specialized institutions schools and special classes were created based on the normality and abnormality guidelines imposed to the Brazilian society (Brasil, 2008).

The nineteenth century was distinguished by several historical events in deaf education in Brazil and other countries. In Brazil the educational management of the deaf students began with Eduard Huet, a deaf teacher formed by the National Institute of the Deaf of Paris, France. He immigrated to Brazil in 1855 to establish a school for deaf people (Honora \& Frizanco, 2009; Rocha, 2010). In collaboration with the government, Huet founded the Imperial Institute of Deaf Mutes (ISM Instituto Imperial de Surdos Mudos), the first institution for deaf education in Brazil, now called National Institute of Deaf Education (INES Instituto Nacional de Educação de Surdos) on September 26, 1857, (Perlin, 2002; Rocha, 2010). Known as the Day of the Deaf, this day was registered in the history of the Brazilian deaf community being celebrated each year since then.

Perlin (2002) reported that the Brazilian families indifference with the deaf children education, as they did not know anything about it, was one of the difficulties found by Huet at that time. Interestingly the methodology used by Huet was based on the combined method developed by Charles Michel De L'Épée at the National Institute for the Deaf in Paris, in which he combined the use of signs with the written French.

De L'Épée advocated in favor of gestural approach in deaf education in the late eighteenth century. His opinion was based on the observation of the visual gestural communication among deaf people that was very efficient. De L’Épée developed an educational method based on sign language of the deaf community, adding new signs approaching the French structurally. He called this system "methodical signs”. De L’Épée educational proposal requested that educators learn sign language and use it as a tool for teaching the spoken and written languages. For De L’Épée the sign language is deaf natural language for developing proper thinking and communication (Lacerda, 1998).

Huet left Brazil in 1861 to create another institute for deaf students in Mexico. Rocha (2010) mentioned that Huet teaching program encompassed the disciplines of writing and reading Portuguese, aspects of religion and social duties, also including Catechism, Geography, History, Arithmetic, Drawing and Commercial Bookkeeping.

In 1878, at the I International Congress on Education of the Deaf that took place in Paris, the deaf have obtained some achievements such as the right to sign documents. In this event, some groups supported the idea that the spoken language was better than the sign language, except for children where sign language would be important for them to communicate (Lacerda, 1998).

Another important event in which oralism was favored was the International Congress of Teachers Deaf held in Milan, Italy, in 1880. As a result of this congress the oralism was declared as the preferred method of instruction for the deaf, based on a clinic vision. Honora \& Frizanco (2009) described that, from that moment, the oral method of teaching was adopted in different European countries, considering that this was the best way of teaching the deaf children at school. This congress was considered a key event in deaf education as it resulted in 
the resumption of Articulated Language for all educational institutions, based on the assumption that sign language would destroy deaf oralization ability (Rocha, 2010). Perlin and Strobel (2006) affirmed that deaf people was subdued to the practices of hearing people, having to abandon their own culture, their identity and underwent an "ethnocentric hearing way" also having to imitate them.

The oralism was chosen for deaf education in an attempt to include them in a hearing society. This was based on the idea that the deaf, despite not having the sense of hearing for speech perception, can communicate through oral language (Soares, 2005). This method, widely held in Europe, recommended oral language as a priority for the integral development of children. For communication with deaf people should be used the spoken language using the auditory pathway (trained) and lip reading. Heinicke was considered the founder of oralism and developed an educational methodology for the deaf called "German method" (Moores, 1978; Lacerda, 1998).

The twenty century is marked by major changes in deaf education with the increased number of schools for the deaf in the world, and opening of some in Brazil including: 1) the Santa Terezinha Institution (St. Therese Institute) for deaf girls in São Paulo; 2) the Concordia School in Rio Grande do Sul; 3) the School for the Deaf in Vitória; 4) the Center for Hearing and Language "Ludovico Pavoni” (CEAL/LP) in Brasilia and others. The oral method was used in most schools including INES (INES, 2010).

Although the sign language was banned in most educational institutions, the ISM continued to use the methodology of Abeé De L’Epée until 1901 (Perlin, 2002). From 1920, there was also an increase of institutions related to special education. Later, during 1930 and 1947, when Dr. Armando Paiva Lacerda was the director in INES, they developed the Pedagogy of the Deaf Mute Amendment that once again emphasized that the oral method was the only way to include the Deaf in the society (Honora \& Frizanco, 2009).

Despite oral methods have become priority in deaf education, they received several criticisms, mainly from the United States of America. It would be difficult to get the children oralized being a very complex task. Moreover, this method did not lead to language development (Lacerda, 1998).

In the 50's and 60's, there was the expansion of private special education entities. Similarly, the public authorities increased the number of services to the disabled, thus offering education services to people with disabilities (Gaviolli, 2008). At the same period, it was created the first Brazilian deaf associations organized exclusively for deaf people that intended to disseminate sign language and help on the construction of deaf identity.

In addition new researches have been done on the linguistics of sign language in the 60's. A research conducted by William Stokoe, an American linguist, pointed the visual-spatial language used by the American deaf community as a sign language when analyzed according to the linguistic patterns. From these studies, visual-spatial language began to be recognized as a valid language, stimulating new research in the study of language acquisition (Stokoe Jr., 2005).

In Brazil, the introduction of people with disabilities, including deaf people, in the general education system was regulated with the Law of Guidelines and Bases of National Education (LDB-Lei de Diretrizes e Bases da Educação), $\mathrm{n}^{\circ}$. 4.024/61 (Brasil, 1961). This law had as one of its goals to guarantee "where it is possible" the right of the "exceptional" to an education within the regular education system. Later, the Law n ${ }^{0}$ 5.692/71 (Brasil, 1971) that regulates the law above led to educational segregation of people with disabilities as it defined the "special treatment" for students with "physical and/or mental disabilities, those who are in considerable age delay, and the gifted ones". Both laws have failed to carry out the regular school system adjustment to start the process of inclusion, reinforcing the maintenance of special classes and institutions.

In the 80's and 90's, researches on sign languages and the acquisition by deaf children had strongly begun (Quadros, 1998). Some studies concluded that sign language can be considered as a language like others, with its own visual-spatial characteristics and grammar. Moreover, studies of language acquisition have shown that the acquisition of sign language by deaf children occurs analogously and at same time to the acquisition of spoken language by hearing children (Salles, Faulstich, Carvalho, \& Ramos, 2004).

Historically the Salamanca Statement is a result of the World Conference on Special Needs Education in Salamanca, Spain, in 1994. It was an instrument in the process of inclusion of people with disabilities into the regular educational system. According to Ferreira (2006), in the period after the Salamanca Statement in 1994, studies on Inclusive Education emerged internationally. The Inclusive Education has become an important area for research, therefore, scientists, students and professionals in the areas of education and health have approached it. This resulted in a profound reflection on education for individuals with educational special needs and influenced 
the development of LDB in Brazil (Brasil, 1994).

The current LDB represented by Law $\mathrm{n}^{\circ}$. 9.394/96, in article 4, recommends the "specialized care" of students with special needs "preferably" in the regular school system. In article 59, it reports that it shall be provided curricula, methods, techniques, educational resources and specific organization to meet this public specific needs, especially those who cannot reach the specified level for completion of primary school, in virtue of their disability, and acceleration for completion in less time school program for gifted ones (Brasil, 1996).

In an Inclusive Education perspective, the proposal is to understand the classroom as a heterogeneous environment that must be conducted with several and different teaching and learning strategies. To Mantoan (2006), the logic division between "normal" and "disabled" students and the types of teaching in "regular" and "special" classes are based on a "deterministic, mechanistic, formalist, and reductionist vision with own modern scientific movement, which ignores the subjective, affective [...], without we could not break with the old school model to produce the overturn demanded by inclusion." In article $24^{\circ}$ "chance of developing in courses and series through learning evaluation" is also guaranteed. Overall the current LDB says that teachers must present proper skills in middle or higher level for specialized care and education. The regular school teachers should be trained to promote the integration of these students in regular classes (Brasil, 1996).

In 2002, the Brazilian Sign Language (Libras - Língua Brasileira de Sinais) is recognized as the official language of the deaf community by the Law $\mathrm{n}^{\circ} 10.436 / 02$ (Brasil, 2002), which points out the duty of the government to guarantee the use and dissemination of Libras as the primer language for deaf communities in Brazil. In fact this law was a result of the deaf community fight, which now is recognized as citizens and members of a deaf culture and not as disabled ones.

Still aiming the deaf education, the Decree $n^{0} 5.626 / 05$ (Brasil, 2005), which regulates Law $n^{\circ} 10.436 / 02$ intends to ensure: 1) the insertion of Libras as a mandatory curricular subject in training courses for teachers in middle and upper level, 2) Portuguese as a second language in education of deaf students, 3) the presence of teachers and Libras interpreters in the classroom, and 4) the guarantee of an oriented service for deaf children with special educational needs not only within the classroom but also in a complementary time into resources classrooms after the regular classes.

In Brazil, the Resolution $n^{\circ} 4$ of 2009 (Brasil, 2009) provides instructions for the further education of people with disabilities, developmental disorders and/or high skills/giftedness. According to this resolution, students with disabilities must be enrolled in the regular school system and in the Specialized Educational Service (AEE), which can be offered in a multifunctional resource room of a teaching institution. Other options include "specialized educational service centers from public network or community institutions, religious or philanthropic nonprofit organizations."

There is an expansion of guidelines complementing the character of special education that ensures the specialized educational treatment complement or supplemental to schooling. However, there is a regression of the inclusion process when the resolution $\mathrm{n}^{\mathrm{o}} 4$ provides the possibility of associating the regular education institution with the Specialized Service Centers for Special Public Education. This allows the Brazilian regular school system to maintain their insufficiently capability of attending these students.

The report titled Deaf People and Human Rights seeks to give an overview of how developing countries deal with the rights of deaf people and their education. According to Hauland \& Allen (2009), sign language was only officially recognized in 44 of the 93 countries surveyed. The report finds that no country completely denies the right of deaf education, since there are one or more schools for the deaf even in countries who claimed not to recognize this right (Bolivia, Eritrea, Guinea, Seychelles and South Korea). However, there is no country where the education system and/or literacy levels are considered completely satisfactory. Participants of this report described that the quality of education is low with a high level of illiteracy, which, according to Hauland \& Allen (2009) is an indicator that there is still a great lack of knowledge about the importance of sign language in deaf education.

Recently in Portugal, Dr. Orquídea Coelho noted that there is a need for a deaf differentiated, tailored and specific training for setting the deaf up on the job market (personal communication). Her studies show that it is still necessary to encourage the training of interpreters to help them in the acquisition of specific knowledge for attending the job market (Coelho, 1998, 2010; Coelho, Cabral, \& Gomes, 2004).

\subsection{Science Education and Teaching Resources in the Deaf Scholar Context}

Science represents the main knowledge gained in the current days (Tenório, Miranda, \& Oliveira, 2000). It is 
through sciences and biotechnology education that starts the student investigative behavior that encompasses the questionings, creativity, capacity for critical analysis, troubleshooting using logical reasoning and individual development from the argument. The result of this practice has great influence in economic and technological development of societies.

The first contact with the scientific world generally happens at the school environment, specifically during teaching chemistry, physics and biology. Scientific literacy plays an important role in the construction of the individual. The scientific knowledge allows the development of the citizenship escaping from the alienation of the modern society (Tenório, Miranda, \& Oliveira, 2000). The Brazilian National Curriculum (Brasil, 1998) present as a fundamental goal to provide "conditions for the student to experience the scientific method [...] from observations, hypotheses, testing them, refuting them [...] working to rediscover the current knowledge."

There are several studies about methods and resources that can be used on teaching sciences and biotechnology including performing experiments, visiting labs and non-formal educational spaces. However, due to the teacher training inability and the economic and social aspects in which the schools are inserted, the scientific method is generally applied incipiently by teachers that teach in an informative, boring and non attractive way (Maradino, 2003). The scientific method is a procedure or set of steps that can be performed to achieve a certain goal, in an organized, logical and systematic way, based on experimentation and observation evidence (Méis, 2007). The literature addressing this methodology with deaf students pointed it as a motivating scientific thinking way (Rumjanek et al., 2012) that can be used for approaching sciences and biotechnology.

Unfortunately, new problems arose for teaching science with the process of inclusion of students with disabilities in regular education. This comprises the need for interpreters and the absence of equivalent signs to scientific terms to be used in several disciplines in Brazil, including biology. The lack of sufficient bilingual teaching glossaries (Libras/Portuguese) and supporting materials are still the main problems for the interpreters and teachers, and also restrain the deaf students in their studies outside the Brazilian educational institution (Marino, 2007). Several errors in the interpretation, unintentional flaws in translations of original texts, the speed of hand movements, and lack of impartiality or ignorance of the content taught in the classroom by those who deal with the deaf students had compromised this teaching and learning process (Marino, 2007).

According to Honora and Frizanco (2009), Libras is a living and formal language that is constantly changing with the inclusion of new signs introduced by the deaf communities according to their needs. De Castro Jr. (2011) draws attention to the need for more research on the process of creating and training signals in Libras within perspectives that deal with regional and grammatical variations and transliteration of the Portuguese Language for the Libras.

The use of alternative methodologies for the generation of didactic resources can maximize the teachinglearning process by stimulating the students' interest by science content (Yamazaki \& Yamazaki, 2006). The process of inclusion of students with disabilities in Brazilian regular education demanded changes on the way how science education occurs at schools. Despite some studies in the literature about methodologies to simplify the learning of science by deaf students, the wide reading is still essential for those seeking to meet adequately this audience and to approach specific contents (Albuquerque, 2007; Medeiros, Mussi, \& Levada, 2008; Tenório, Miranda, \& Oliveira 2009; Castiblanco, 2010).

The bilingual education adopted in the regular school system assists the teaching-learning of deaf students as the visual-spatial language enables their thinking and learning in an active form. Capovilla declared that if language has the important function of allowing interpersonal interaction, it also has the vital role to enable intrapersonal thinking, the training and recognition of concepts, proper problem solving mechanisms and conscious learning (Capovilla, 2000). Therefore, the presence of the interpreter in the classroom is essential as they allow deaf student to interact with hearing people and to acquire the knowledge transmitted by the teacher (Bernardino \& Lacerda, 2007). In addition, vision is the most important sense for deaf people as through this sense they interact with society. Thus, the use of visual resources (structural models, photos, games) and conducting experiments in classrooms or laboratories may assist them in the acquisition of knowledge though linking theory to practice.

Axt (1991) justifies the importance of experimentation as it connects the science teaching with the reality of scientific work. It promotes the acquisition of knowledge and mental development of all students (Marandino, 2003; Méis, 2007). The use of experimentation in science education of deaf students results in similar learning levels (Rumjanek et al., 2012). Importantly, it cannot be concluded that the students, including deaf ones, will learn only by using visuals material but probably it will be more efficiently the use of this kind of material for 
complementary and paradidactical purpose. Experiments should be considered as a practical method for application of theoretical concepts addressed by the teacher for all students in an inclusive and integrative way (Oliveira, 1992).

3D-Models can also be interesting resources to work with biological structures. Albuquerque (2007) reported the development of models representing the male and female reproductive organs used as teaching resources for deaf students with positive results. Albuquerque emphasized the importance of group dynamics to interpret the work of Mourão (2006), highlighting the interaction among the students when there is discussion of ideas in which all participants have the same purpose. In a study with deaf students, Albuquerque observed that most students interacted with each other as well as with the author during the dynamics, also expressing their opinions and questions about the topic.

Another teaching strategy for teaching science is the use of educational games. For Campos, Felicio \& Bortoloto (2003), the teaching-learning process is facilitated when it is based on a play activity, since students are "excited" when using an interactive and fun strategy. The educational games also allow students to establish relationships among the studied contents and the day-to-day practices (Borges \& Schwaurz, 2005). Besides to facilitate and promote the acquisition of knowledge, games contribute to the personal and social development and assist on building new discoveries, helping on the student personality development. This playful activity can also promote students interest to scientific knowledge in a simplest form (Campos, Felicio, \& Bortoloto, 2003).

According to Borges and Schwarz (2005), teachers should also create or adapt games based on school contents as they develop skills and competencies doing this activity. This also encourages them to study and learn new concepts. Campos, Felicio \& Bortoloto (2003) showed that during the game application, the teacher assumes the role of mediator, driver, sponsor and evaluator of the teaching-learning process, which makes him/her closer to the students.

An educational game is a visual instrument that promotes interaction among students and can be an important tool to facilitate the acquisition of knowledge by deaf students, getting similar or even better results compared to the hearing student's teaching-learning process.

Non-formal education also serves as tool to facilitate the construction of knowledge as it draws students' attention. This is due to the use of locations outside the school environment, which promotes students interest. Non-formal education in these places including museums, science centers and any other space that develops activities directed to a particular purpose is characterized by encouraging learning school diverse contents (Gohm, 1999; Vieira, Bianconi, \& Dias, 2005).

\subsection{Final Considerations}

The Brazilian experience and deaf culture revealed several important factors that should not be ignored in the teaching and learning process of the deaf community. It is still essential the emergence of new signs to represent the most diverse content in several areas including science and that are still absent in Libras and in several other visual-spatial languages from several countries. The production and use of materials with a significant visual approach and visits to non-formal places can also contribute significantly to the deaf learning process. Either directly or in a complementary mode, these resources can consolidate the understanding of the information provided by teachers and interpreters. Moreover, the prior interaction between interpreters and teachers can contribute to the uniformity in the presentation of concepts, helping the interpreters in their training since they are required to "know" almost everything when acting as a bridge between teacher and the deaf student.

\section{Acknowledgements}

We thank to FAPERJ, CAPES, and CNPq for the fellowships and financial support.

\section{References}

Agrawal, Y., Platz, E. A., \& Niparko J. K. (2008). Prevalence of Hearing Loss and Differences by Demographic Characteristics among US Adults, Data from the National Health and Nutrition Examination Survey, 1999-2004. Archives Internal Medicine, 168, 1522-1530. http://dx.doi.org/10.1001/archinte.168.14.1522

Albuquerque, L. D. (2007). Orientação Sexual para Alunos Surdos, Trabalhando com Dinâmicas de Grupo e Modelos Concretos. Monografia em Ciências Biológicas, Universidade Federal Fluminense, 68 p.

Axt, R. (1991). O Papel da experimentação no ensino de ciências. In Moreira, M. A., \& Axt, R. (Eds.), Tópicos em Ensino de 
Ciências, Porto Alegre, Sagra, 7990.

Bear, M. F. (2008). Neurociências, desvendando o sistema nervoso. Tradução por, Carla Dalmaz. 3rd Edition, Porto Alegre, Artmed.

Bernardino, B. M., \& Lacerda, C. B. F. (2007). O intérprete de Língua Brasileira de Sinais no contexto de escola inclusiva. In, Congresso de Iniciação Científica/Mostra Acadêmica 5, 15, 2007. Universidade Metodista de Piracicaba (UNIMEP). Anais. Piracicaba, Editora da Unimep, p 12.

Borges, R. M. R., \& Schwuarz, V. (2005). O papel dos jogos educativos no processo de qualificação de professores de ciências. In, Encontro IberoAmericano de Coletivos Escolares e Redes de Professores de Ciências que fazem Investigação na sua Escola, 4., Lajeado RS.

Brasil (1961). Ministério da Educação. Lei de Diretrizes e Bases da Educação Nacional. LDB Lei no 4.024, 20 de dezembro de 1961.

Brasil (1971). Ministério da Educação. Lei de Diretrizes e Bases da Educação Nacional. LDB nº 5.692, de 11 de agosto de 1971.

Brasil (1994). Declaração de Salamanca e linha de ação sobre necessidades educativas especiais. Brasília, UNESCO, 1994.

Brasil (1996). Ministério da Educação. Lei de Diretrizes e Bases da Educação Nacional. LDB Lei nº 9.394, de 20 de dezembro de 1996.

Brasil (1998). Ministério da Educação e do Desporto. Parâmetros Curriculares Nacionais, Ciências Naturais. Brasília, MEC, 1998.

Brasil (2002). Ministério da Educação. SEESP. Lei de LIBRAS nº 10.436, de 24 de abril de 2002.

Brasil (2005). Decreto $n^{\circ}$ 5.626, de 22 de dezembro de 2005. Regulamenta a Lei no 10.436, de 24 de abril de 2002, que dispõe sobre a Língua Brasileira de Sinais Libras, e o art. 18 da Lei no 10.098, de 19 de dezembro de 2000.

Brasil (2008). Política nacional de educação especial na perspectiva da educação inclusiva. Inclusão, Revista da Educação Especial, 4, 717.

Brasil (2009). Conselho Nacional de Educação. Câmara de Educação Básica. Resolução nº 04, de 2 de outubro de 2009.

Campos, L. M., Felicio, A. K. C., \& Bortoloto, T. M. (2003). A produção de jogos didáticos para o ensino de ciências e biologia, uma proposta para favorecer a aprendizagem, Caderno dos Núcleos de Ensino, 3548.

Capovilla, F. C. (2000). Filosofias educacionais em relação ao surdo, do oralismo à comunicação total ao bilinguismo. Revista Brasileira de Educação Especial, 6, 99-116.

Carneiro, L. L. F. (2005). Surdez, perdas e ganhos. Ciências \& Cognição, 6, 133-141.

Castiblanco, B. A. B. (2010). La argumentacion en el discurso académico em lengua de senas colombiana (L.S.C.) en el area de biologia en educandos sordos de educacion media del Colegio San Francisco IED Jornada manana de Bogota. 2010. 169 f. Dissertação (Mestrado em Educação), Pontificia Universidad Javeriana, Bogota.

Coelho, O. (1998). Depois da Escola? Formação, autoformação e transição para a vida activa dos surdos em Portugal. Universidade do Porto, Faculdades de Psicologia.

Coelho, O., Cabral, E., \& Gomes, M. C. (2004). Formação de surdos, ao encontro da legitimidade perdida. Educação, Sociedade e Cultura, 22, 153-181.

Coelho, O. (2010). Da lógica da justificação à lógica da descoberta. Ser surdo num mundo ouvinte, um testemunho autobiográfico. Cadernos de Educação. Pelotas, 36, 197-221.

Ferreira, W. B. (2006). Inclusão x exclusão no Brasil, reflexões sobre a formação docente dez anos após Salamanca. In D. Rodrigues (org.), Inclusão e Educação, doze olhares sobre a educação inclusiva. São Paulo: Summus.

Gaviolli, A. de F. (2008). A educação de surdos em Cacoal/RO, um encontro com a realidade. 103 p. Dissertação (Mestrado em Educação) Programa de Pósgraduação em Educação Universidade Federal do Mato Grosso do Sul.

Gohm, M. G. (1999). Educação nãoformal e cultura política. Impactos sobre o associativismo do terceiro setor. São Paulo: Cortez.

Hauland, H., \& Allen, C. (2009). Deaf People and Human Rights. Report of the World Federation of the Deaf.

Honora, M., \& Frizanco, M. L. E. (2009). Livro Ilustrado de Língua Brasileira de Sinais, desvendando a comunicação usada pelas pessoas com surdez. São Paulo: Ciranda Cultural.

INES (Instituto Nacional de Educação de Surdos) (2010). O surdo e a história de sua educação. http://www.ines.gov.br/ines_livros/31/31_PRINCIPAL.HTM

De Castro Jr., G. (2011). Variação Linguística em Língua de Sinais Brasileira, Foco no Léxico. 2011. 123 f. Dissertação (Mestrado em Línguística), Universidade de Brasília, Departamento de Linguística, Português e Línguas Clássicas. Brasília. 
Lacerda, C. B. F. (1998). Um pouco da história das diferentes abordagens na educação dos surdos. Caderno CEDES, 19, 6880. http://dx.doi.org/10.1590/S0101-32621998000300007

Lent, R. (2010). Cem bilhões de neurônios, conceitos fundamentais de neurociências (2. ed.). São Paulo: Atheneu.

Lorenzini, N. M. P. (2004). Aquisição de um conceito científico por alunos surdos de classes regulares do ensino fundamental. Dissertação (Mestrado) Programa de PósGraduação em Educação Científica e Tecnológica Universidade Federal de Santa Catarina, 155 p.

Mantoan, M. T. E. (2006). O direito de ser, sendo diferente, na escola. In D. Rodrigues (org.), Inclusão e Educação, doze olhares sobre a educação inclusiva. São Paulo: Summus.

Marandino, M. (2003). A prática de ensino nas licenciaturas e a pesquisa em ensino de ciências, questões atuais. Caderno Brasileiro de Ensino de Física, 20, 168-193.

Marino, M. L. (2007). O ensino da biologia, o intérprete e a geração de sinais. Dissertação (Mestrado em Lingüística)Instituto de Letras, Universidade de Brasília, 144 p.

Medeiros, R., Mussi, A. A., \& Levada, C. L. (2008). O ensino de física para alunos surdos, desafios e possibilidades. Congresso Científico Uniraras, 3., Congresso de Iniciação Científica CNPq, 2., Encontro Internacional sobre Envelhecimeto, 1., 2008. São Paulo. Anais. São Paulo, Fundação Hermínio Ometto. 1, 90-94.

Méis, L. (2007) O Método Científico (5 ed.). Rio de Janeiro.

Miranda, C. R., Dias, C. R., Pena, P. G. L., Nobre, L. C. C., \& Aquino, R. (1998). Perda auditiva induzida pelo ruído em trabalhadores industriais da região metropolitana de Salvador, Bahia. Informe Epidemiológico do SUS, 7, 87-94. http://scielo.iec.pa.gov.br/pdf/iesus/v7n1/v7n1a05.pdf

Moores, D. (1978). Educating the Deaf, Psychology, Principles and Practice. Boston: Houghton Mifflin Co.

Moreira, M. A. (2011). Teorias de Aprendizagem (2 ed.). Ampliada. São Paulo: EPU, 242 p.

Mourão, S. J. G. (2006). A dinâmica de grupo-promoção de saúde mental na $3^{a}$ idade. 50 p. Trabalho de Conclusão de Curso (Especialista em Saúde Mental)-Educação Continuada-Universidade Estadual Vale do Acaraú, Sobral.

Oliveira, R. J. (1992). A crítica ao verbalismo e ao experimentalismo no ensino de química e física. Revista Química Nova, 15, 86-89.

Padden, C., \& Humphries, T. (2006). Inside deaf culture. Cambridge, MA: Harvard University Press, 217 p.

Perlin, G. T. T. (2002). História dos surdos. (col.) Abreu, A. C. de, Sumpf, M., Silva, V., \& Miranda, W., Florianópolis, UDESC/CEAD, $107 \mathrm{p}$.

Perlin, G. T. T., \& Strobel, K. L. (2006). Fundamentos da educação de surdos. Material didático para o curso Letras/Libras da Universidade Federal de Santa Catarina, UFSC, 66 p.

Quadros, R. M. (1998). O contexto escolar do aluno surdo e o papel das línguas. Revista Espaço. INES., 1, 25-29.

Quadros, R. M. (2003). Situando as diferenças implicadas na educação de surdos, inclusão/exclusão. Ponto de Vista, Florianópolis, 5, 81-112.

Redondo, M. C. F., \& Carvalho, J. M. (2001). Deficiência auditiva. In, Cadernos da TV escola, Brasília, MEC, SEED, 63 p.

Rocha, S. (2010). Memória e História, A Indagação de Esmeralda. Coleção de Cadernos Acadêmicos. Editora Arara Azul, Petrópolis, Rio de Janeiro.

Rumjanek, V. M., Barral, J., Schiaffino, R. S., Almeida, D., \& Pinto-Silva, F. E. (2012) Teaching Science to the Deaf-A Brazilian Experience. 6th International Technology, Education and Development Conference, Valencia, 5-7 March 2012, 361-366.

Salles, H. M. M. L., Faulstich, E., Carvalho, O. L., \& Ramos, A. A. L. (2004). Ensino de língua portuguesa para surdos. Brasilia, MEC, SEESP. 139 p.

Silva, J. M. (2006). Pensamento e linguagem em Lev Vygotsky e Jean Piaget. Instituto Politécnico da Guarda [s.n.].

Silveira, L. C. de L. (2008). Os sentidos e a percepção. In R. Lent (org.) Neurociência da Mente e do Comportamento (p. 151158). Rio de Janeiro: Guanabara Koogan.

Skliar, C. (1997). Uma perspectiva sóciohistórica sobre a psicologia e a educação dos surdos. In Educação e exclusão, abordagens socioantropológicas em educação especial. Porto Alegre, Mediação, 105-153.

Soares, M. A. L. (2005). A educação do surdo no Brasil (2. ed.). Campinas:, Autores Associados. 128 p.

Stokoe Jr., W. C. (2005). Sign language structure, an outline of the visual communication systems of the American deaf. Journal of Deaf Studies and Deaf Education, 10, 337. http://dx.doi.org/10.1093/deafed/eni001

Tenório, L. M. F., Miranda, A. C., \& Oliveira, L. R. (2000). O ensino de ciências na educação de surdos, a interface com a educação física. In Encontro Nacional em Pesquisa de Educação em Ciências. ENPEC, 7. Florianópolis. 
Vieira, V., Bianconi, M. L., \& Dias, M. (2005). Espaços nãoformais de ensino e o currículo de ciências. Ciência e Cultura, 57, 21-23.

Vygotsky, L. S. (1993). Pensamento e linguagem. São Paulo Martins Fontes.

Yamazaki, S. C., \& Yamazaki, R. M. (2006). Sobre o uso de metodologias alternativas para ensino-aprendizagem de ciências. Jornada de Educação da Grande Região de Dourados, 3, Dourados, UEMS. 